\title{
Perancangan Wheel Mobile Robot Sebagai Modul Praktikum Mikrokontoler
}

\author{
Mohammad Iqbal \\ Dosen Fakultas Teknik, Program Studi Teknik Elektro \\ Universitas Muria Kudus \\ Email: iqbal.umk@gmail.com \\ Solekhan \\ Dosen Fakultas Teknik, Program Studi Teknik Elektro \\ Universitas Muria Kudus \\ Email: solekhan@gmail.com
}

\begin{abstract}
ABSTRAK
Robot merupakan bentuk aplikasi embedded system yang menggunakan mikrokontroler sebagai pengendalinya. Belajar berdasarkan secara aplikasif akan lebih menarik, sehingga diharapkan minat belajar akan meningkat, apalagi untuk aplikasi yang saat ini masih menjadi trend yaitu tentang robotika. Target khusus yang ingin dicapai dalam penelitian ini adalah pembuatan prototipe modul praktikum mikrokontroler aplikatif berbasis wheel mobile robot. Modul robot beroda ini didesain sedemikian rupa, sehingga komponen-komponen yang diintegrasikan tetap dapat mengadopsi praktikum sesuai dengan materi yang diajarkan dalam mata kuliah mikrokontroler. Metode yang digunakan dalam penelitian ini adalah menggunakan pendekatan penelitian pengembangan atau lebih dikenal dengan Research \& Development (R\&D). Hasil yang telah dicapai dalam penelitian ini adalah desain konstruksi robot dan desain rangkaian pada robot.
\end{abstract}

Kata kunci: Mikrokontroler, Robot Beroda, Modul Praktikum

\begin{abstract}
Robot is an application type of embedded systems using a microcontroller as the controller. Learning based on the application be more attractive, so it is expected to increase interest in learning, especially for applications is still a trend that is about robotics. Specific targets to be achieved in this research is to make an applicative microcontroller module prototype based mobile wheel robot. This robotic module is designed in such a way that the integrated components can be adopted the material taught in courses microcontroller in accordance with the practice. The method used in this research is the development research approach or known as the Research \& Development $(R \& D)$. In this research, the design of the robot construction and its circuits have been completed.
\end{abstract}

Keywords: Mikrokontroller, Wheel Mobile Robot, Practice Module

\section{PENDAHULUAN}

Kehadiran dunia komputer dalam bentuk jaringan yang terintegrasi secara internasioanal telah mendobrak dan menghapus batas-batas wilayah, tempat, jenjang kehidupan. Teknologi ini telah siap dipakai dengan harga murah sehingga tidak hanya orang-orang berduit saja yang dapat menikmati. Fleksibilitas penggunaan komputer terjadi karena dikembangkannya secara terpadu antara perangkat keras dan perangkat lunak dalam satu sistem. Sistem semacam ini sering disebut sebagai programmable-based system.

Dengan adanya program, komputer dapat dengan mudah dan cepat diubah fungsi dan aplikasinya. Bahkan sekarang telah sampai pada sistem yang dapat bekerja dengan banyak pekerjaan (multi task). 
Dalam dunia industri manufaktur dan dunia jasa layanan penggunaan komputer tidak kalah pertumbuhannya. Otomatisasi, pengukuran, dan pengendalian proses produksi dan jasa layanan telah menggunakan komputer sebagai mesin otomatis. Wujudnya tidak dalam bentuk personal computer tetapi lebih kecil dalam satu chip yang disebut dengan Mikrokontroler.

Mikrokontroler sering disebut juga dengan one chip microcomputer. Mikrokontroler telah dilengkapi dengan CPU, Memory, I/O, Counter/Timer dan komunikasi serial. Fungsinya menjadi sangat kompak dan murah harganya. Untuk memfungsikan mikrokontroler diperlukan programprogram yang dapat di download ke dalam memori chip. Dengan demikian disamping kompetensi antar muka secara hardware diperlukan kompetensi pengembangan program atau sering disebut kompetensi pemrograman.

Rata-rata mahasiswa yang masuk perguruan tinggi swasta (PTS) adalah mereka yang tidak lolos masuk ke perguruan tinggi negeri, sehingga bisa dikatakan tingkat kecerdasan dan minat belajar mahasiswa yang diterima di PTS adalah rata-rata menengah ke bawah. Oleh karena itu, diperlukan kreatifitas dosen untuk memberikan pembelajaran yang menarik dan mampu menarik minat mahasiswa sangatlah diperlukan. Dalam kurikulum teknik elektro universitas muria kudus, terdapat dua matakuliah yang berhubungan langsung dengan mikrokontroler yaitu Mikrokontroler I dan Mikrokontroler II. Modul praktikum untuk kedua mata kuliah tersebut, sebenarnya sudah ada, tapi mungkin kurang menarik dalam model yang kemasan box seperti biasanya.

\subsection{Pengembangan Media Pembelajaran}

Menurut UU No. 20 Tahun 2003 tentang Sistem Pendidikan Nasional (Depdiknas, 2003), pembelajaran diartikan sebagai proses interaksi peserta didik dengan pendidik dan sumber belajar pada suatu lingkungan belajar. Pembelajaran adalah suatu usaha yang sengaja melibatkan dan menggunakan pengetahuan profesional yang dimiliki guru untuk mencapai tujuan kurikulum. Pembelajaran merupakan suatu aktivitas yang dengan sengaja untuk memodifikasi berbagai kondisi yang diarahkan untuk tercapainya suatu tujuan yaitu tercapainya tujuan kurikulum.

Dari berbagai pendapat yang dikemukakan di atas dapat disimpulkan bahwa media media pembelajaran merupakan segala sesuatu yang dapat dijadikan alat bantu untuk menyampaikan materi pembelajaran oleh guru kepada siswa sehingga pesan atau informasi yang disampaikan dapat lebih mudah diterima dan dipahami. Berbagai media dari berbagai macam model dapat digunakan guru untuk membantu proses belajar mengajar.

Media pembelajaran yang baik harus memenuhi beberapa syarat. Media pembelajaran harus meningkatkan motivasi pembelajar. Penggunaan media mempunyai tujuan memberikan motivasi kepada pembelajar. Selain itu media juga harus merangsang pembelajar mengingat apa yang sudah dipelajari selain memberikan rangsangan belajar baru. Media yang baik juga akan mengaktifkan pembelajar dalam memberikan tanggapan, umpan balik dan juga mendorong mahasiswa untuk melakukan praktek-praktek dengan benar.

Ahwadz Fauzi Madhawirawan (2010) ${ }^{[2]}$, dalam penelitiannya merancang dan membuat modul Trainer Mikrokontroler ATMega32 Sebagai Media Pembelajaran Pada Kelas XI Program Keahlian Audio Video di SMK Negeri 3 Yogyakarta, dan mendapatkan hasil kelayakan trainer mikrokontroler ATmega32 berdasarkan hasil uji kelayakan yaitu, 1) evaluasi validasi ahli media dinyatakan sangat layak dengan persentase bernilai $81,9 \%$; 2) validasi ahli materi dinyatakan sangat layak dengan persentase bernilai $89,1 \%$; 3) uji kelayakan dengan pemakai skala besar dinyatakan layak dengan persentase sebesar $70 \%$.

Sedangkan Putu Sudira (2006) ${ }^{[4]}$, melakukan Peningkatan Pencapaian Kompetensi Pemrograman Mikrokontroler Menggunakan Model Pembelajaran Pemecahan Masalah "IDEAL" Mahasiswa S1 Pendidikan Teknik Elektronika Fakultas Teknik Universitas Negeri Yogyakarta, dan mendapatkan temuan-temuan sebagai berikut:

a. Sekuen materi kompetensi pemrograman mikrokontroler harus dituangkan dalam modul-modul sebagai jabaran dari uraian sub-sub kompetensi. Sekuen materi pencapaian kompetensi dijabarkan dalam bentuk peta pencapaian kompetensi sehingga jelas keterkaitan antara satu modul dengan modul lainnya. 
b. Ketercapaian kompetensi pemrograman dapat ditentukan dengan analisis kemampuan

c. Mengidentifikasi masalah, pengembangan algoritma dan flowchart, penulisan program menggunakan instruksi yang selaras dengan flowchart, melakukan kompilasi, download, dan uji atau tes hasil program.

d. Kompetensi pemrograman mikrokontroler dapat dibangun dengan memberikan latihan dan kasus-kasus dengan penyelesaian terstruktur sesuai dengan model "IDEAL" (Identifying problems, Defining problems, Exploring alternative approach, Action on a plan, and Loooking at the effect),

e. Kompetensi pemrograman mikrokontroler secara perorangan belum dapat dikatakan secara pasti peningkatannya karena penelitian ini tidak didahului dengan penelitian sebelumnya sebagai ukuran awal kemampuan kompetensi pemrograman mahasiswa.

\subsection{Mobile Robot}

Mobile robot merupakan salah satu kategori robot, yang menunjukkan adanya fungsi untuk berpindah tempat. Pada awal perkembangannya, mobile robot menggunakan roda (wheel) untuk dapat berpindah tempat, namun saat ini telah dikembangkan robot yang dapat berpindah menggunakan kaki (leg), sehingga lebih dapat melewati area yang tidak dapat dilewati dengan roda.

Mobile robot juga dapat diberikan berikan kecerdasan buatan, sehingga melalui informasi yang didapat dari sensor, maka robot dapat berjalan mengikuti garis dan menghindari halangan.

Penelitian tentang robot cerdas pengikut garis yang juga dikembangkan oleh Juing-Huei Su et.al. (2010) ${ }^{[3]}$ yang ditujukan untuk tingkat pengenalan (pemula) dan hasil yang didapat adalah bahwa dengan menggunakan algoritma mean square errors, robot dapat melaju dengan kecepatan 1,3 $\mathrm{m} / \mathrm{detik}$.

\subsection{Mikrokontroler ATMega32 ${ }^{[1]}$}

AVR (Alf and Vegard's Risc Processor) merupakan salah satu jenis mikrokontroler yang di dalamnya terdapat berbagai macam fungsi. AVR memiliki keunggulan dibandingkan dengan mikrokontroler jenis lain, keunggulannya yaitu AVR memiliki kecepatan eksekusi program yang lebih cepat karena sebagian besar instruksi dieksekusi dalam 1 siklus clock, lebih cepat bila dibandingkan dengan mikrokontroler jenis MCS51 yang memiliki arsitektur CISC (Complex Instruction Set Compute) dimana mikrokontoller MCS51 membutuhkan 12 siklus clock untuk mengeksekusi 1 instruksi. Selain itu kelebihan mikrokontroler AVR memiliki POS (Power On Reset), yaitu tidak perlu adanya tombol reset dari luar karena cukup hanya dengan mematikan supply, maka secara otomatis AVR akan melakukan reset. Untuk beberapa jenis AVR terdapat beberapa fungsi khusus seperti ADC, EEPROM sekitar 128 bytes sampai dengan 512 bytes.

Dalam penelitian ini yang digunakan adalah mikrokontroler AVR tipe ATmega32 standar. Perbedaanya dengan AVR tipe ATmega32L terletak pada besarnya tegangan kerja yang dibutuhkan. Untuk ATmega32L tegangan kerjanya antara 2,7V - 5,5V sedangkan untuk ATmega32 hanya dapat bekerja pada tegangan $4,5 \mathrm{~V}-5,5 \mathrm{~V}$.

ATmega32 berdasarkan informasi dalam datasheet ATMEL merupakan mikrokontroler AVR 8 bit berkemampuan tinggi dengan daya yang rendah, dan memiliki 32 x 8 general purpose working register. Kecepatan eksekusi program yang dimiliki ATmega32 lebih cepat karena sebagian besar instruksi dieksekusi dalam 1 clock dengan arsitektur RISC hampir mencapai 16 MIPS pada frekuensi $16 \mathrm{MHz}$. Memori data dan program yang tidak mudah hilang (Nonvolatile Program and Data Memories) dengan Pemrograman Flash memiliki kapasitas 8K Bytes, dan memiliki daya tahan 10000 siklus tulis/hapus program. Fasilitas timer/counter yang ada pada mikrokontroler ini terdiri dari dua buah Timer/Counter 8 bit dan satu buah Timer/Counter 16 bit. Fitur-fitur tersebut adalah fitur-fitur yang digunakan dalam proyek akhir ini. Fitur-fitur lainnya yang disediakan ATmega32 adalah adanya 4 kanal PWM, 6 kanal ADC 10 bit, pemrograman serial USART, On-chip Analog Comparator, dan interrupt. 


\section{METODOLOGI PENELITIAN}

Metode yang digunakan dalam penelitian ini adalah menggunakan pendekatan penelitian pengembangan atau lebih dikenal dengan Research \& Development (R\&D). Dalam bidang pendidikan, produk-produk yang dihasilkan melalui penelitian R\&D diharapkan dapat meningkatkan produktivitas pendidikan, yaitu lulusan yang jumlahnya banyak, berkualitas, dan relevan dengan kebutuhan.

Tahap-tahap penggunaan Metode Research and Development :

a. Validasi Desain

Validasi dilakukan oleh dosen pengampu mata kuliah mikrokontroler terhadap hasil desain modul praktikum yang telah dibuat.

b. Revisi Desain

Setelah melalui proses validasi desain dilanjutkan dengan revisi desain. Sampai langkah ini produk sudah dalam bentuk modul kemudian di uji cobakan kepada mahasiswa di laboratorium.

c. Uji Coba

Uji coba dinilai berdasarkan uji fungsi masing-masing komponen modul, kestabilan kerja, konstruksi, kemudahan penggunaan, kelengkapan dan kesesuaian dengan kebutuhan kompetensi.

d. Revisi dan Uji Pemakaian di laboratorium

Setelah melalui revisi uji coba dilakukan dengan menggunakan modul praktikum di laboratorium.

e. Produksi

Setelah revisi berdasarkan masukan dosen program studi, lalu modul praktikum diproduksi atau diperbanyak secukupnya..

\section{HASIL PENELITIAN DAN PEMBAHASAN}

\subsection{Desain Modul Robot}

Desain I/O (input/output) modul robot masih tetap mangacu kepada modul praktikum yang lama. Meskipun ada beberapa komponen dihilangkan, tetapi ditambahkan beberapa komponen lainnya sebagai gantinya. Desain ini dimaksudkan penggunaan modul robot tetap dapat mengadopsi semua pokok bahasan yang diajarkan dalam mata kuliah mikrokontroler. Detail tentang perbedaan modul robot dan modul praktikum sebelumnya dapat dilihat pada tabel 1 .

Tabel 1. Perbandingan modul Robot Dengan Modul Praktikum Sebelumnya

\begin{tabular}{lll}
\hline Sub Bahasan & \multicolumn{1}{c}{ Modul Praktikum Sebelumnya } & \multicolumn{1}{c}{ Modul Robot } \\
\hline Output & LED & LED \\
& Seven Segment & [tidak ada] \\
& LCD & LCD \\
& [tidak ada] & Pengendali Motor DC Kanan dan \\
& & Kiri yang dapat dikendalikan \\
& & secara individual termasuk arah \\
Input & Push Button & putar simit Switch sebagai sebagai \\
& Keypad & sensor deteksi tabrakan \\
ADC & Potensiometer & n/a \\
& & Foto dioda sebagai sensor garis \\
& & Mic condensator sebagai sensor
\end{tabular}




\begin{tabular}{lll} 
Timer/Counter & Menggunakan I/O yg ada & Menggunakan I/O yg ada \\
Serial & Serial & Serial \\
Interupsi & Pushbutton & Pushbutton / IR Module Receiver \\
& UART & UART \\
& Timer & Timer \\
PWM & Kecerahan nyala LED & Kecepatan putar motor kanan dan \\
& & kiri \\
\hline
\end{tabular}

\subsection{Desain Konstruksi Robot}

Desain modul robot mengacu pada bentuk robot beroda pengikut baris, yaitu ada bagian chasis, bagian sensor, bagian utama dan tampilan LCD.

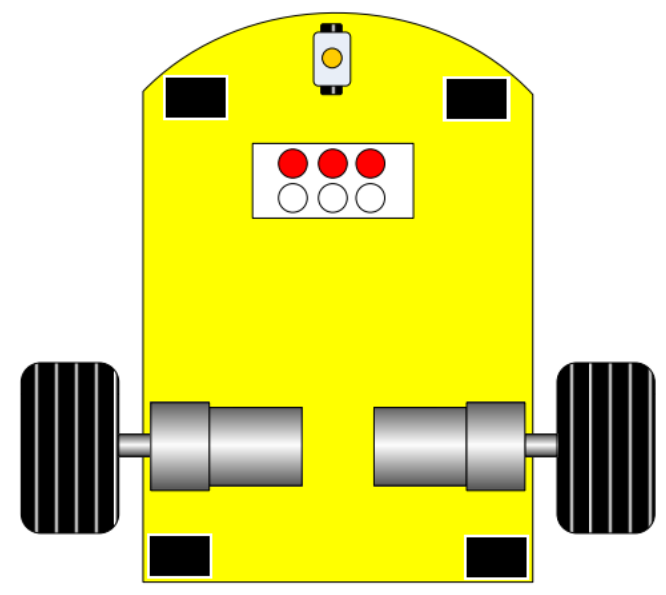

\section{Gambar 1. Desain Bagian Chasis Robot (Tampak Bawah)}

Pada bagian chasis seperti pada gambar 1 dipasang komponen-komponen seperti motor DC kanan, motor DC kiri, ball caster, sensor fotodioda untuk deteksi garis dan limit switch. Limit switch sebagai sensor tabrakan depan dan belakang.

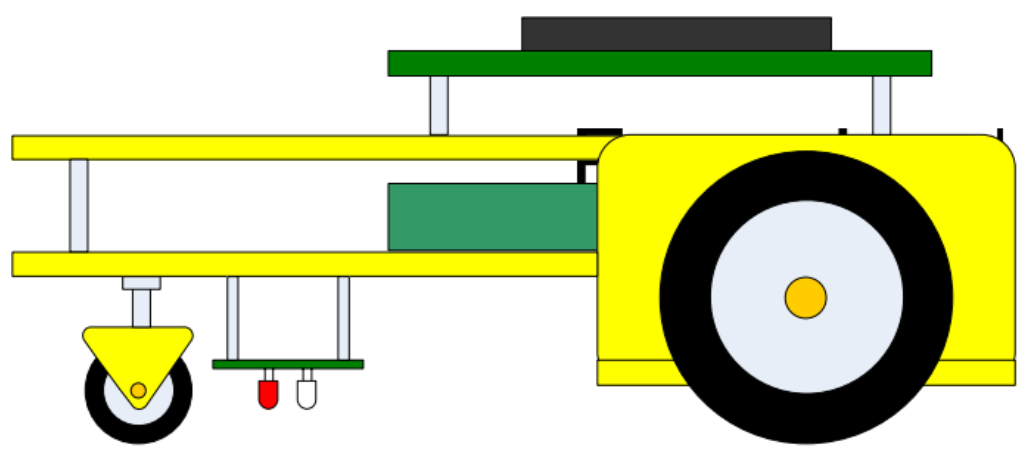

Gambar 2. Desain Modul Robot (Tampak Samping) 
Gambar 2 menunjukkan rencana desain modul robot yang akan dibuat. Bagian bawah adalah chasis robot beroda, bagian tengah adalah bagian utama yang terdiri dari rangkaian sistem minimum mikrokontroler ATMega32, rangkaian driver motor, rangkaian LED, rangkaian konversi serial TTL ke RS232, rangkaian sensor suara, rangkaian buzzer dan rangkaian penerima infra merah dari remote control. Sedangkan bagian paling atas adalah modul tampilan LCD.

\subsection{Desain Rangkaian}

Desain rangkaian untuk robot menggunakan aplikasi gratis (freeware) yaitu ExpressSCH yang merupakan bagian dari software ExpressPCB untuk versi 7.0.0.

Rangkaian sistem minimum yang digunakan adalah seperti pada gambar 3. Pada rangkaian sistem minimum terdapat rangkaian power-on reset atau reset secara manual menggunakan push button. Selain itu, pada sistem minimum terdapat rangkaian yang berhubungan dengan penggunaan ADC (Analog to Digital Conversion), sehingga memungkinkan untuk penggunaan tegangan referensi melalui pin AVCC atau melalui AREF. Pemilihan sumber tegangan referensi dilakukan melalui program dengan mengatur register tertentu yang berhubungan dengan ADC.

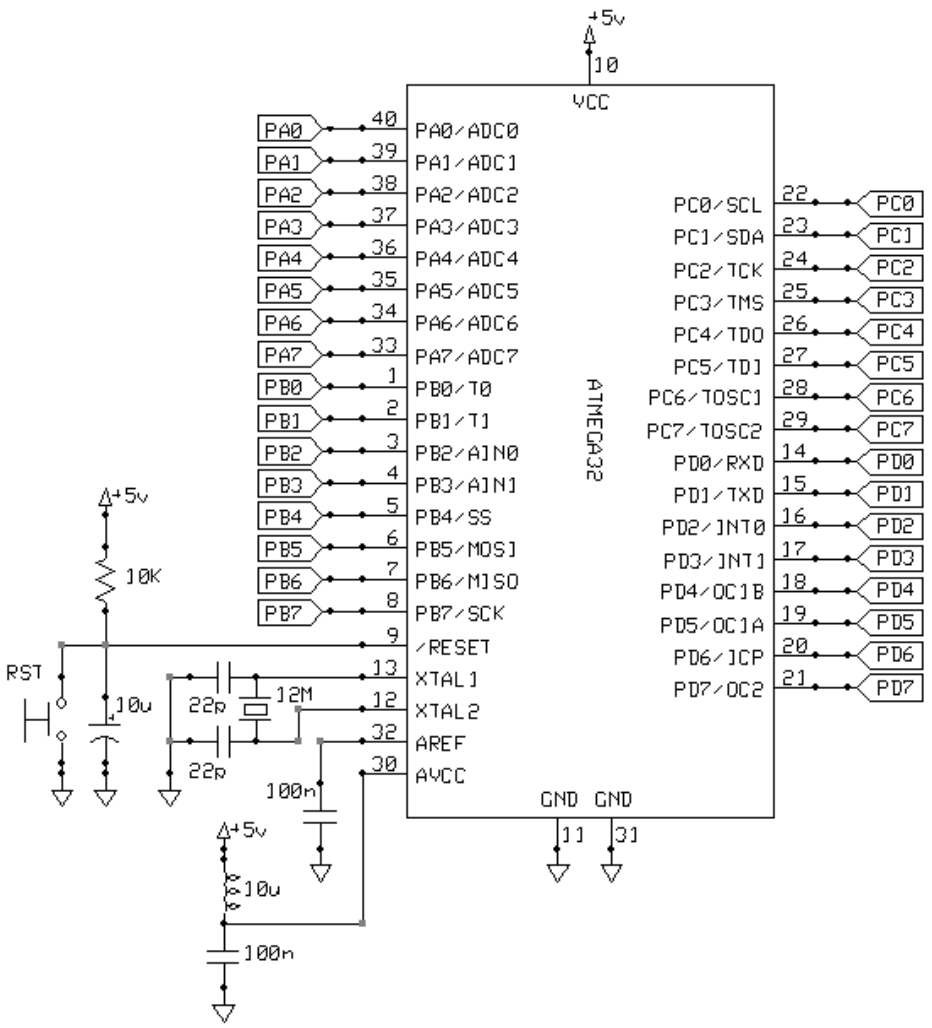

\section{Gambar 3. Rangkaian Sistem Minimum ATMega32}

Gamnbar 4 menunjukkan rangkaian regulator tegangan 5 Volt DC. Pada rangkaian regular terdapat dioda 1N4001 sebagai pengaman polaritas tegangan dari pemasangan terbaik. Input tegangan adalah minimal 8 Volt atau nominal yang digunakan 9 Volt dari sumber baterai atau catu daya. 


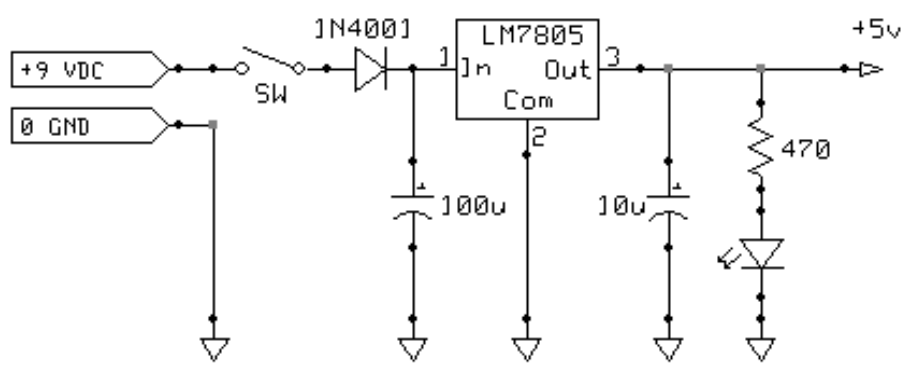

\section{Gambar 4. Rangkaian Regulator Tegangan 5 Volt DC}

Rangkaian LED pada gambar 5 menggunakan resistor $470 \mathrm{ohm}$ sebagai pembatas arus. Konfigurasi rangkaian LED adalah pull-up ke +5 Volt, yang menunjukkan bahwa untuk menyalakan LED maka pin mikrokontroler yang terhubung dengan LED harus diberi logika tinggi atau High $(\mathrm{H})$. Sebaliknya jika logika pada pin adalah rendah atau Low (L), maka LED akan mati.

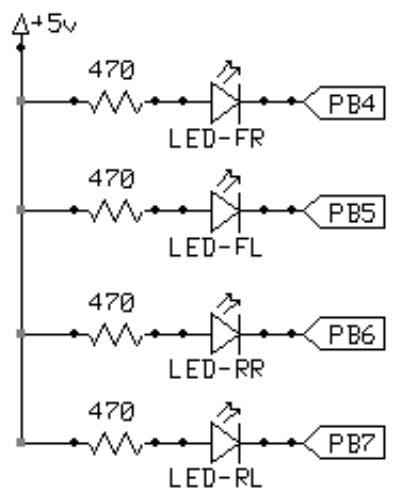

\section{Gambar 5. Rangkaian LED}

Gambar 6 menunjukkan rangkaian buzzer. Buzzer dapat digunakan sebagai alarm atau indikator pertama kali power-on atau yang lainnya.

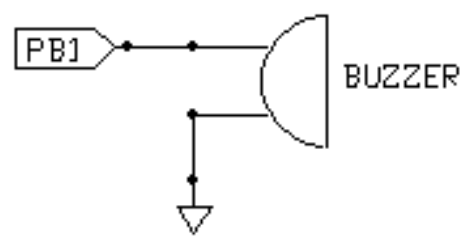

\section{Gambar 6. Rangkain Buzzer}

Rangkaian LCD pada gambar 7 menggunakan koneksi data interface 4-bit, hal ini dimaksudkan untuk menghemat penggunaan port pada mikrokontroler. Selain port data pada LCD, terdapat port control, yaitu RS (Register Select), RW (Read/Write) dan E (Enable). 


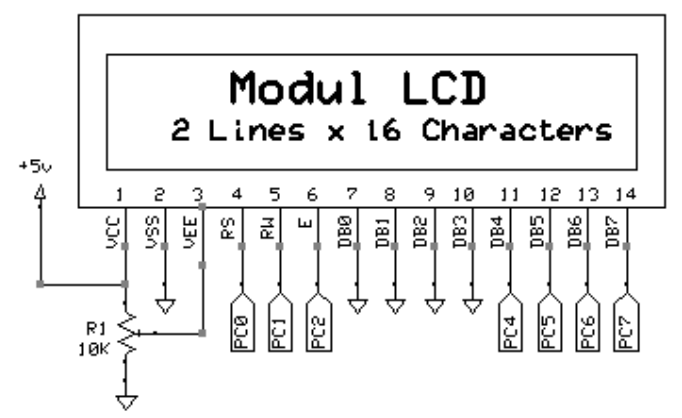

Gambar 7. Rangkaian LCD

Rangkaian driver motor DC seperti pada gambar 8 menggunakan IC L293D yang merupakan berisi dua driver $\mathrm{H}$-bridge motor yang dapat dikendalikan secara terpisah. Dengan pengendalian secara terpisah untuk motor kanan dan motor kiri, maka robot dapat berjalan maju, mundur, belok kanan, belok kiri, putar kanan dan putar kiri.

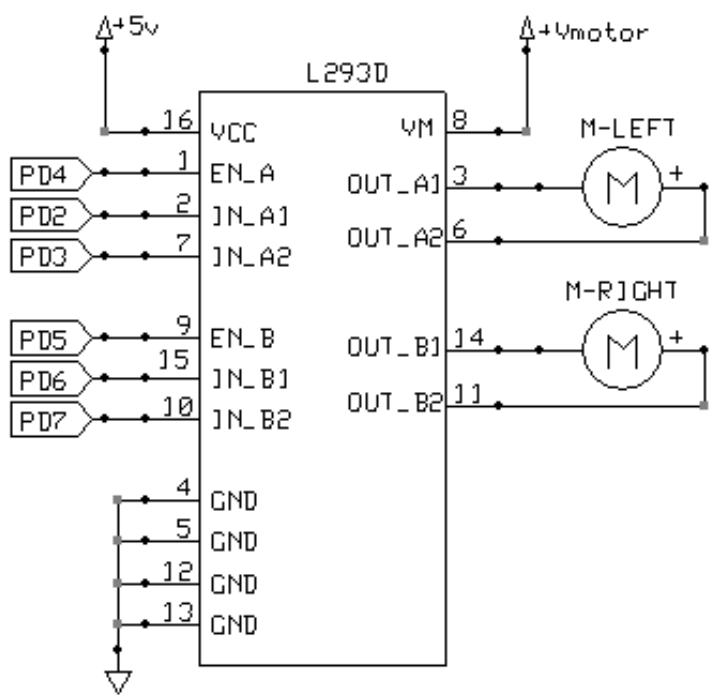

\section{Gambar 8. Rangkaian Driver Motor Menggunakan IC L293D}

Gambar 9 menunjukkan rangkaian sensor infra merah termodulasi untuk menangkap sinyal data dari remote control infra merah. Dengan mengetahui data yang dipancarkan oleh remote control infra merah, saat tombol tertentu ditekan, maka dapat dilakukan pengendalian robot dengan menggunakan remote control infra merah.

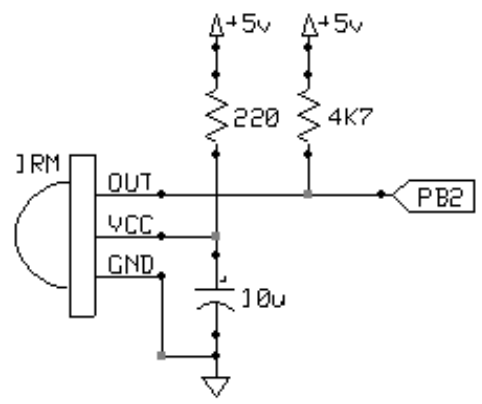

Gambar 9. Rangkaian Penerima Sensor Infra Merah Dari Remote Control 
Rangkaian limit switch seperti gambar 9 digunakan sebagai sensor sentuh, ketika robot menabrak suatu halangan di depan atau di belakangnya. Dua limit switch dipasang di bagian depan sebelah kanan dan kiri, sedangkan dua lainnya dipasang di bagian belakang, sebelah kanan dan kiri.

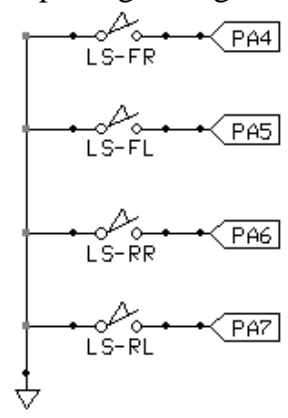

Gambar 10. Rangkaian Limit Switch Sebagai Sensor Sentuh/tabrakan

Fotodioada pada rangkaian sensor cahaya pada gambar 11 digunakan untuk mengukur besarnya cahaya dari LED yang dipantulkan. Jika media pantulan adalah berwarna gelap maka cenderung cahaya akan terserap dan sedikit yang akan dipantulkan. Sedangkan jika media pantulan berwarna cerah, maka cahaya yang dipantulkan akan lebih banyak. Dengan menggunakan kedua prinsip di atas, maka robot dapat diprogram untuk mengikuti garis (line follower). Pada rangakaian sensor ini terdiri dari tiga pasang fotodioda dan LED.
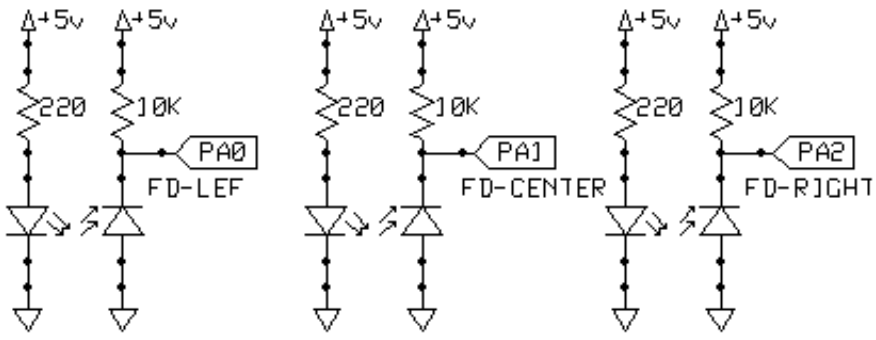

Gambar 11. Rangkaian Sensor Cahaya

Penggunaan sensor suara pada rangkaian gambar 12, akan memberikan kemampuan robot untuk beraksi berdasarkan suara, misalnya jika robot 'mendengar' tepukan tangan yang keras atau bunyi lain yang keras maka robot akan beraksi untuk berjalan maju, mundur, belok atau yang lainnya.

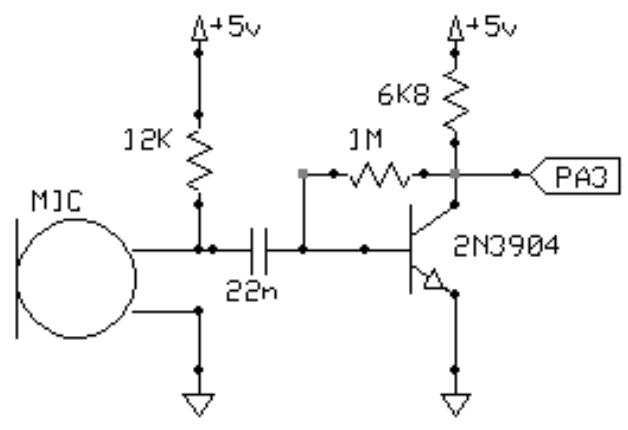

\section{Gambar 12. Rangkaian Sensor Suara}

Tegangan level RS232 umumnya digunakan pada komputer pada port serialnya. Sedangkan pada port serial mikrontroler umumnya menggunakan taraf tegangan TTL. Agar komputer dan mikrokontroler dapat berkomunikasi secara serial, maka diperlukan rangkaian konversi untuk 
mengubah taraf tegangan RS232 ke TTL dan sebaliknya. Rangkian konversi ini dapat menggunakan IC Max232 atau yang sejenisnya, tetapi bisa juga menggukan rangkaian transistor seperti pada gambar 13.

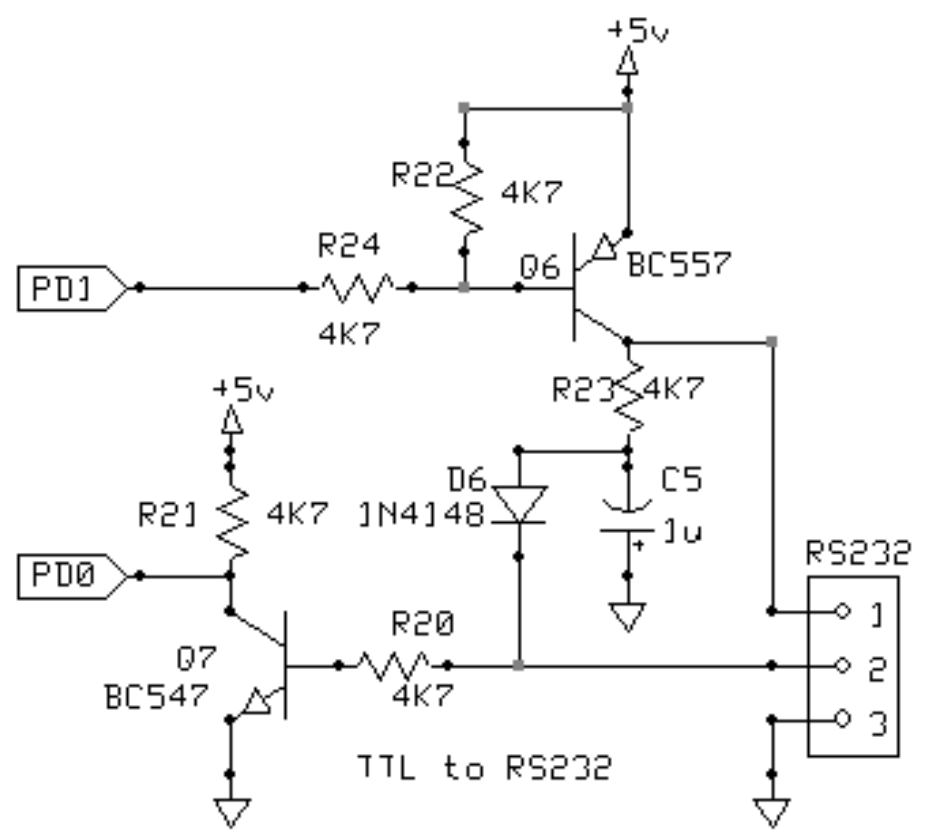

Gambar 13. Rangkaian Konversi UART RS232

\section{KESIMPULAN}

Modul aplikatif robot didesain berdasarkan komponen-komponen dalam modul mikrokontroler, sehingga modul robot diharapkan tetap dapat mengadopsi pokok bahasan yang diajarkan dalam matakuliah mikrokontroler. Beberapa komponen dalam modul praktikum lama tetap digunakan, sedangkan untuk komponen yang dihilangkan, maka diganti dengan komponen yang lain yang dirancang untuk aplikasi pada robot beroda.

\section{UCAPAN TERIMA KASIH}

Terima kasih kepada DIKTI (Direktorat Jenderal Pendidikan Tinggi). Artikel ilmiah ini merupakan publikasi Penelitian Dosen Pemula yang didanai tahun 2013 oleh Direktorat Penelitian dan Pengabdian Kepada Masyarakat, Direktorat Jenderal Pendidikan Tinggi, Kementerian Pendidikan dan Kebudayaan, sesuai dengan Surat Perjanjian Pelaksanaan Penugasan Penelitian Dosen Pemula Bagi Dosen Perguruan Tinggi Swasta Antara Ditjen Dikti dengan Kopertis Wilayah VI Nomor: 225/SP2H/PL/DIT.LITABMAS/VI/2013, tanggal 27 Juni 2013; Antara Kopertis Wilayah VI dengan Universitas Muria Kudus Nomor : 005//SP2H/KL/KOPERTIS6/VIII/2013, tanggal 27 Agustus 2013; Antara Universitas Muria Kudus dan Ketua Peneliti Nomor: 188/Lemlit.UMK/B.07.31/VIII/2013, tanggal 28 Agustus 2013.

\section{DAFTAR PUSTAKA} Flash, ATMEL

ATmega32/ATmega32L 8-bit Microcontroller with 32KBytes In-SystemProgrammable

[2] Ahwadz Fauzi Madhawirawan (2010), Trainer Mikrokontroler Atmega32 Sebagai Media Pembelajaran Pada Kelas XI Program Keahlian Audio Video di SMK Negeri 3 Yogyakarta, Jurusan Teknik Elektronika, Fakultas Teknik, Universitas Negeri Yogyakarta 
[3] Juing-Huei Su, Chyi-Shyong Lee, Hsin-Hsiung Huang, Sheng-Hsiung Chuang \& Chih-Yuan Lin (2010). An intelligent line-following robot project for introductory robot courses, World Transactions on Engineering and Technology Education, Vol.8, No.4, pp.455-461

[4] Putu Sudira (2005), Peningkatan Pencapaian Kompetensi Pemrograman Mikrokontroler Menggunakan Model Pembelajaran Pemecahan Masalah "IDEAL" Mahasiswa S1 Pendidikan Teknik Elektronika Fakultas Teknik Universitas Negeri Yogyakarta, Fakultas Teknik Universitas Negeri Yogyakarta. 